\title{
Przełom czy kontynuacja? Słowacka myśl polityczna po roku 1867
}

\begin{abstract}
Goszczyńska Joanna, Przełom czy kontynuacja? Słowacka myśl polityczna po roku 1867 (Breakthrough or Continuation? Slovak Political Thought after 1867). "Poznańskie Studia Slawistyczne" 17. Poznań 2019. Publishing House of the Poznań Society for the Advancement of the Arts and Sciences, Adam Mickiewicz Univesity, pp. 43-57. ISSN 2084-3011.

The article focuses on two texts (Jozef Podhradský, The secret history of Pan-Slavism and Michal Miloslav Hodža Vieroslavín), that are located on the periphery of Slovak political thought, but they are a very significant testimony to the intersection of emancipation ideas in the period of dualistic monarchy. These important texts bring a proposal of various solutions to the arrangement of Slovak-Hungarian relations in the new situation after 1867. Unfortunately, one of them was not published at all (written by Hodža in 1867-1870), while the second one, published in Novi Sad in 1868 , remained almost unnoticed.

They show how close the idea of messianism was to Slovak thinkers at that time. (This particularly applies to M.M. Hodža). Under her influence, they present their visions of Europe and the monarchy. They also show the Slovaks as a chosen nation that will play a decisive role in the revive common Europe.
\end{abstract}

KeYwords: dualism; political thought; messianism; Pan-Slavism; Europe

Enrique Florescano, w artykule O rozlicznych pożytkach z historii, jednym z dziesięciu tekstów meksykańskich intelektualistów zawartych w tomie Po co nam historia?, precyzyjnie ujął problem, którego uniwersalny charakter odnosi się nie tylko do gruntu meksykańskiego, pisząc:

W epokach, w których zderzają się ze sobą dwie, lub więcej, sprzeczne interpretacje przeszłości, zaostrza się wrażliwość na to, co historyczne - grupy, klasy i narody z niepokojem usiłują odnaleźć swoje korzenie historyczne; rozpowszechnia się i nasila poszukiwanie świadectw i argumentów historycznych, które utwierdziłyby własne racje i zadały kłam racjom przeciwnika. W czasach, w których walczy się równocześnie o przeszłość i teraźniejszość, pojawia się gwałtownie krytyka historyczna, rewizja świadectw stanowiących oparcie własnej i antagonistycznej interpretacji przeszłości (Florescano, 1985, 73). 
Refleksja Florescano wyłoniła się w mojej pamięci pod wpływem ponownej lektury wydanej na Słowacji książki młodych węgierskich historyków Rozštiepená minulost', którą autor wstępu, słowacki historyk Roman Holec, uznał za nowe otwarcie w konstruktywnym dialogu węgierskich i słowackich historyków a zarazem wyzwanie dla tych ostatnich do jego podjęcia (Holec, 2013, 15). Jej lektura wywołała we mnie - nie będącej ani historykiem, ani badaczem słowackim - mieszane uczucia, ale uwrażliwiła też na większą ostrożność $\mathrm{w}$ posługiwaniu się syntetyzującymi pojęciami. Rozumiem intencję autorów przeciwstawienia obiegowemu terminowi spoločná minulost' terminu rozštiepená minulost', jednakże nawet $\mathrm{w}$ ich tekstach przedstawiana przeszłość często jawi się jako spoločná właśnie, a nie rozštiepená. Ponadto ich spojrzenie na wspólną przeszłość - nie tożsamą, ale należącą do obu narodów - potwierdza jedno z założeń relatywizmu poznawczego mówiące, że historyk jest częścią swojej historii. To tytułem wstępu, jako że będę się do tej pracy odwoływać.

To, co chciałabym ująć w swojej refleksji, to spojrzenie na dwa teksty, będące również świadectwem myślenia o tym, co Słowaków i Węgrów może łączyć, jaka była ich przeszłość i jaką przyszłość dla obu narodów widzą ich autorzy po roku 1867. Artykuł nie pretenduje zatem w żadnym razie do całościowego ujęcia zasygnalizowanego w tytule problemu, jest bardziej rewizją świadectw, o jakiej pisze Florescano, a może raczej należałoby powiedzieć staromodnie - interpretacją, dotyczy bowiem utworów dotychczas nieinterpretowanych. Są one z pozoru zupełnie odmiennego charakteru. Ktoś może bowiem zapytać, co łączy obszerny, niepublikowany, wierszowany poemat Michala Miloslava Hodžy Vieroslavín z mało znaną publicystyczną broszurą Jozefa Podhradskiego Tajná história panslavizmu..., poza tym, że nie weszły one, niestety, do obiegu czytelniczego lub weszły w bardzo małym zakresie, a zatem pozostały martwym elementem toczącego się w czasach, kiedy powstały, dialogu politycznego. To „niestety” dotyczy zwłaszcza poematu Hodžy, w którym odnaleźć można zadziwiająco aktualne myśli i propozycje organizacji wspólnej europejskiej przestrzeni. Otóż łączy te utwory przede wszystkim fakt, że wyrażane w nich poglądy kształtują się pod wyraźnym wpływem idei mesjańskiej. Można też wskazać inne jeszcze zbieżności. Obydwaj autorzy piszą je w latach pobytu poza terytorium dzisiejszej Słowacji (Podhradský od 1863 roku w Nowym Sadzie, Hodža od 1867 roku w Cieszynie), poza 
głównym nurtem słowackiego ruchu narodowego. Dla Hodžy nieangażowanie się w życie publiczne było wręcz warunkiem jego spokojnej egzystencji z materialnym zabezpieczeniem przez władze wiedeńskie. Wspólny jest też moment ich powstania - tuż po roku 1867, a zatem u progu okresu dualizmu, trwającego pół stulecia, którego wagę w kształtowaniu się słowacko-węgierskich relacji trudno przecenić. Jak pisał jeden z autorów wspomnianej publikacji Rozštiepená minulost’:

Jeho vplyv možno cítit' až dodnes - v mad'arskom společenskom vedomí je to obdobie známe ako zlatá doba, obdobie modernizácie, budovania štátu, ako i dynamickej národnej sebarealizácie. Ešte dodnes je z neho citel’ný istý pocit nadradenosti voči susedom (ktorý je však rozporuplný, lebo sa mieša s frustráciou z neskorších neúspechov). Slováci zasa hodnotia toto obdobie negatívne, ako plné prekážok a krivd voči ich národnému formowaniu (Zahorán, 2013, 98).

U schyłku lat 60. XIX wieku rozwiązanie wielu kwestii stało jeszcze pod znakiem zapytania. Ugoda austro-węgierska dała Węgrom dużą swobodę w porządkowaniu wewnętrznych problemów, zlikwidowała potrzebę zawierania kompromisu z niewęgierskimi narodami, stworzyła warunki do rozwiązania problemów narodowościowych z pozycji siły. Ale to przyniosą lata późniejsze. Natomiast rok 1868 przyniósł ustawę narodowościową, która teoretycznie miała gwarantować narodom niewęgierskim liczne prawa. Wierzy w to jeszcze Podhradský, który z atencją odnosi się w swoim tekście do Ferenca Deaka, uważanego za ojca tej ustawy i głównego inspiratora porozumienia $\mathrm{z}$ Austrią.

Broszura Podhradskiego ukazała się w 1868 roku w Nowym Sadzie, gdzie, jak wspominałam, wówczas żył. Hodža pisał swój poemat pomiędzy rokiem 1867 a 1870, w ostatnich latach swojego życia, ale jego utwór nie doczekał się publikacji. Zachował się w czterech wariantach, na podstawie których Samuel Ossuský przygotował do druku jedną - jak twierdził - najpełniejszą wersję ${ }^{1}$.

Koncentrując się na tych dwóch tekstach, mam pełną świadomość, że sytuują się one poza głównym nurtem słowackiej myśli politycznej okresu dualizmu, w którym centralną pozycję zajmowała tzw. Nowa Szkoła

${ }^{1}$ Osuský pisze o tym we wstępie do opracowanego maszynopisu (Hodža), który znajduje się w archiwum Maticy Slovenskej w Martinie (cf. Osuský). Wszystkie cytaty pochodzą z tego maszynopisu. Numer strony znajduje się w tekście zasadniczym, po cytacie. 
Słowacka z jej głównym rzecznikiem - Jánem Palárikiem. Jej koncepcje, bardzo istotne w słowacko-węgierskim dialogu, są już dosyć dobrze przebadane $^{2}$. Aby jednak nie pozostawić ich zupełnie bez echa, zwłaszcza że będę przywoływać poglądy Palárika, w kilku zdaniach je przybliżę. Nowa Szkoła Słowacka, w opozycji do tzw. starej szkoły, konserwatywnego nurtu kontynuującego szturowsko-hurbanowski model słowackości, zrywa z ideą słowiańską, otwiera się na pluralistyczną Europę Zachodnią i stawia na współpracę z węgierskimi liberałami. Rewitalizuje zatem w wielu aspektach wcześniejszy nurt, krytyczny wobec modelu szturowskiego, reprezentowany przez Štefana Launera czy Sama Vozára. Jej organem prasowym były wychodzące w Peszcie „Slovenské noviny”. Główny rzecznik Nowej Szkoły, Ján Palárik, bardziej znany jako redaktor i dramatopisarz niż jako myśliciel polityczny, ponad 10 lat spędził w modernizującym się w tych latach w szybkim tempie Budapeszcie, będącym ważnym ośrodkiem słowackiego życia narodowego. Stwarzało mu to możliwość oglądu sytuacji z odmiennej perspektywy, niż zamieszkujący w Słowacji działacze narodowi. Ukształtowany intelektualnie nie poprzez lektury rosyjskich słowianofilów i panslawistów, jak np. Štúr, ale przez angielską myśl filozoficzną (Thomasa Hobbsa, Adama Smitha, Johna Locke'a, Stuarta Milla [Martinkovič, 2006, 841]) lansował przede wszystkim postawę obywatelską, jako jedynie skuteczną w walce o swobody obywatelskie i narodowe. Sceptyczny wobec Austrii, ich gwaranta widział w ustroju konstytucyjnym proponowanym przez Węgrów. Odwoływał się przy tym do wspólnego dziedzictwa historycznego. Warto w tym miejscu przypomnieć, że austrosceptykiem stał się również po 1849 roku Štúr, przedtem wierny monarchii i w imię tej wierności i wiary w jej instytucjonalne wsparcie walczący po jej stronie w rewolucyjnym konflikcie. Jednakże w jego wypadku rozczarowanie polityką Austrii doprowadziło do tego, że stał się zagorzałym zwolennikiem procarskiego panslawizmu, podczas gdy Palárik widział rozwiązanie dla Słowaków we współpracy z węgierskimi liberałami w ramach Królestwa Węgierskiego, które było dla niego niekwestionowalną ojczyzną. Notabene był w związku z tym oskarżany o „madziaroństwo”. Głoszone przez Palárika poglądy polityczne stanowią ważny głos

${ }^{2}$ Spośród badaczy słowackich sporo miejsca tej problematyce poświęca ostatnio, między innymi, Marcel Martinkovič, a wcześniej Tibor Pichler i Rudolf Chmel. 
w narodowym dyskursie emancypacyjnym. I, co ważne, głos słyszalny, opiniotwórczy, czasami współbrzmiący z głosami przedstawicieli innych nacji zamieszkujących Królestwo Węgierskie, i potwierdzający wielotorowość słowackiej myśli politycznej.

O ile jednak poglądy Palárika od dawna budzą zainteresowanie badaczy, to całkowicie poza zasięgiem ich zainteresowania znajdują się prace Podhradskiego i Hodžy. A są one interesującym świadectwem krzyżowania się idei emancypacyjnych, prób godzenia odmiennych rozwiązań w nowej sytuacji, jaka powstała po ugodzie austro-węgierskiej.

Trzeba przyznać, że Jozef Podhradský, który swoją wizję ówczesnej sytuacji kulturowej zawarł w broszurze Tajná história panslavizmu vôbec a uhorských Slovakov zláśte, nie był myślicielem specjalnie oryginalnym. Jego próba włączenia Węgrów w panslawistyczny projekt kreślący przyszłość Słowaków świadczy o wpływie wielu krążących w tym czasie w słowiańskim świecie idei. Nie ulega wątpliwości, że bliskie są mu koncepcje Jána Palárika, formułowane w duchu słowacko-węgierskiego pojednania, ale widać też wpływy wielu nurtów myśli słowianofilskiej. W tym miejscu nie mogę nie wspomnieć o bodajże jedynym w całej literaturze przedmiotu komentarzu poświęconym omawianemu dziełu, jaki znalazł się w artykule Michala Kocáka, wieloletniego pracownika Macierzy Słowackiej w Martinie, zamieszczonym, notabene anonimowo, w tomie $K$ problematike slovenského romantizmủ. Kocák poświęca tej broszurze jedno tylko zdanie, wyliczając problemy, jakie autor podejmuje. Pozwolę je sobie przytoczyć in extenso:

Problematiku Slovanstva a panslavizmu rozobral (Podhradský) aj v d’alšej svojej práci, Tajná história panslavizmu, kde poukázal na stav západnej Európy, vymeranie svetohistorických národov, na budúcnost' Slovanstva, na panslavizmus a panrusizmus i na

${ }^{3}$ Tom wyszedł w 1972 roku jako publikacja Maticy slovenskej w Martinie, w niewielkim nakładzie 150 egzemplarzy, z dopiskiem: „Materiál len pre študijné účely!”. Dwa teksty opublikowane zostały anonimowo: jeden poświęcony Matorze M.M. Hodžy (dziś już wiemy, że jego autorem był Pavol Vongrej, który miał wówczas, po 1968 roku, ograniczone możliwości publikowania) drugi Podhradskiemu. Autorstwo Kocáka potwierdza fakt, że identyczny fragment dotyczący analizowanego utworu znajduje się w jego tekście omawiającym twórczość Podhradskiego, będącym częścią przygotowywanej przez Kocáka edycji jego dzieła. Tekst datowany jest na grudzień 1995 - dzieła zebrane Podhradskiego nie zostały do tej pory opublikowane. 
uhorských Slovakov, ktorí z objektívnych príčin stali sa prvými panslávmi (Kocák, 1972, 185).

Wymienione problemy, to tytuły poszczególnych rozdziałów utworu, z pominięciem ostatniego, najbardziej interesującego i znaczącego, zatytułowanego Politicko-národná buducnost' Mad'arov. A to on właśnie stanowi kwintesencję poglądów słowackiego myśliciela, w wielu aspektach zbliżonych do stanowiska Palárika ${ }^{4}$.

Podhradský po nakreśleniu - zgodnie z obiegową optyką typową dla narracji słowianofilskich i panslawistycznych - opozycji pomiędzy Europą Zachodnią a światem słowiańskim przechodzi do wyłożenia i uzasadnienia swojej propozycji wyjścia z kryzysu, w jakim znalazła się Europa. Uważa, że dwa ludy/narody Słowianie i Węgrzy mogą stać się narzędziami powszechnego odrodzenia. To połączenie misji Słowian we współpracy z innym narodem nie jest zupełnym novum w koncepcjach ówczesnych myślicieli. Mickiewicz rolę taką przypisywał Słowianom i Francuzom. W swojej argumentacji Podhradský odwołuje się z jednej strony do sfery religijnej, z drugiej do wspólnej przeszlości. Jest ona wprawdzie „slavno-žalostná”, ale jest ogniwem spajającym, stwarzającym szansę wspólnego zaistnienia i odegrania ważnej roli również w przyszłości:

Čo sa aj Prussko na ujmu geographickeho Rakúska hmotne rozširílo, a ešte snad víacej rozšíri, predci z pôdy rakúsko-uhorskej majú dva národy slavnejší výhlad do historickej buducnosti, nežli ono. Národy dva, ktoré majú za sebou slavno-žalostnú minulost', ktoré ale povolané sú v novej svetohistorickej epoche čestnú rollu vésti, myšlienku pravej svobody krestianskej nie len v theoriách predkládat' svetu, ale ju aj s d ob rou v ô 1 o u, ku ktorej sa západ pozvzniest nemohol, v život skutočne uvádzat' (Podhradský, 1868,3$)^{5}$.

Wzmacniając i uwiarygodniając swoją argumentację, Podhradský wszystkie te cechy, które w historiozofiach słowiańskich myślicieli przypisywane były Słowianom bądź poszczególnym narodom słowiańskim

${ }^{4}$ Trudno dziś stwierdzić, czy brak ten jest efektem cenzury, czy też zadziałała autocenzura, a raczej należałoby powiedzieć świadome przemilczenie. Identyczny kształt tego fragmentu w późniejszym tekście Kocáka, z 1995 roku, potwierdzałby hipotezę o świadomym przemilczeniu.

${ }^{5}$ Rozstrzelone pismo zastosowane zostało przez autora. 
przypisuje też Węgrom, chociaż nie omieszka wytknąć im chwilowego skażenia Zachodem:

Dva tito národové, impregnovani nerozvitým semenom pre budúcnost', sú S 1 o v a né a M a d'a ri, jedni i druhí bez radostnej minulosti, jedni i druhí národ mladý, života plný, dobrej vôle schopný [...] za slobodu mret' hotoví - ačkolvek, čo zvlášt' o Mad'aroch plati, západným kalem na ten čas zmýlení (Podhratský, 1868, 3).

Podstawowym warunkiem, jaki musi spełniać naród aspirujący do odegrania w przyszłości przywódczej/odrodzeniowej roli jest predyspozycja do realizowania ideałów wolnościowych opartych na wartościach chrześcijańskich oraz gotowość do czynu. Za taki naród uznaje Podhradský obok Słowian - również Węgrów. Nieuzasadnione są zatem ich obawy przed nastaniem ery słowiańskiej, ponieważ są predestynowani do tego, aby stać się jej elementem konstytutywnym. Pozwolę sobie na przytoczenie dłuższego cytatu, odzwierciedlającego tok myślenia autora, w którym splata się argumentacja polityczna z religijną:

pravá tato sloboda aj s družkámí svojími, dobrou vôlou a súhlasným činom, je v budúcom, už už svitajúcom veku svetohistorickom novom, per excellentiam veku slovanskom, ktorého nového veku Mad'ar lekat sa nemá, lebo i on jako Mad'ar nosi v sebe a v duchu národnosti svojej semeno pre vek tento, je tiež čo Mad'ar k an di dá t o m jeho! Jako mohli Mad’ari dosial v centrum a súsedstve dosavádného svetohistorického národa Romansko-Germanského setrvávat aj politične aj národne, prečo by nemohli aj politične aj národne setrvávat aj v svetohistorickej epoche všeslovanskej, a to v koncerte harmonickom v uvádzani v život slobody tej, ku ktorej Syn Boži povýšil národy (Podhratský, 1868, 23).

Strategia autora zdaje się zmierzać ku temu, aby zrelatywizować negatywne nastawienie Węgrów do narodów słowiańskich postrzeganych przez pryzmat obsesyjnie wręcz przypisywanego im panslawizmu. Jak przypomina József Demmel obawa Węgrów przed Rosją była wyraźnie artykułowana przez węgierskich działaczy narodowych już w latach 40. Jako przykład przywołuje on fragment wypowiedzi Miklósa Wesselényiego z 1843 roku:

V našej vlasti je málo tých, ktorí nevedia, kol'ko cudzích a domácich poverených a delegátov z Ruska, najmä kazatel'ov, lákalo a poburovalo už odjakživa slovanské, grécke a valašské obyvatel'stvo ... Vytýčeným ciel'om bolo oslabovat' štáty a ich vládu tam, kde žijú slovanské národy, aby ich takto odcudzili a posilnili moc vlády ruskej (Demmel, 2013, 90). 
Konsekwencją tych lęków było oskarżanie wszystkich Słowian o panslawizm. W okresie dualizmu oskarżenia te przybrały na sile i kierowane były zwłaszcza pod adresem słowackich działaczy narodowych oraz polityków. Podhradský stara się dowieść, że obawy te są zupełnie bezpodstawne. Ważnym elementem jego rozważań jest zarysowanie różnicy pomiędzy panslawizmem a panrusizmem, czyli, jak pisze, politycznym panslawizmem, który był największym straszakiem owych czasów. Panslawizm będący wielką ideą jest już jego zdaniem faktem dokonanym i w kształcie, w jakim Podhradský go nakreślił, akceptowalnym dla Europy. Problem polega na tym, że w swojej skrajnej postaci, panrusizmu, stanowi niebezpieczeństwo politycznego przeorganizowania przestrzeni europejskiej. To jednak, czy tak się stanie, zależy, zdaniem autora, od postawy, jak to określa, ciemiężycieli słowiańskich narodów. Pisze:

Rozvije - vtelesníli sa idea Panslavismu v Panrussimus? Na t’ažkú túto otázku neomýlne pravá odpoved je lahká, ked' povieme, a odôvodníme, že ani Russi, ani Česi, Srby, Slováci atd. Panrussismu nechcejú, nehladaju, nežiadajú si, ale že Panrussismus tento, čili aj politické gravitovánie roztratených kmenov slovanských pod jednu russkú berlu, závisi jedíne od potlačovatelov týchto slovanských kdekady morených a umrtvovaných historie mučeníkov (Podhratský, 1868, 10).

Przechodząc do uzasadnienia swojego twierdzenia autor wyraża przekonanie, że narody słowiańskie chcą się rozwijać samodzielnie, a nie wcielone do Rosji. Odrębność polityczna leży w ich interesie, podobnie jak w interesie samej Rosji. „W objęcia panrusizmu”, jak pisze, co byłoby jego zdaniem katastrofą, mogłaby Słowian popchnąć jedynie kolonialna polityka niesłowiańskich narodów monarchii (Podhratský, 1868, 10). Rosja nie ma w tym żadnego interesu, ponieważ każdy słowiański naród włączony w obręb Rosji na drodze przemocy, przysporzyłby jej tylko nowych problemów, stałby się nową/drugą Polską (Podhratský, 1868, 24).

Warto zauważyć, że w tym punkcie poglądy Podhradskiego znacznie odbiegają od panslawistycznych pomysłów Štúra, który w Rosji widział mocarstwo jednoczące pod swoimi skrzydłami wszystkie narody słowiańskie. Zdaniem autora analizowanego dzieła Rosja nie potrzebuje innych plemion słowiańskich, tych, które żyją pod innym panowaniem. Nie potrzebuje ich terytoriów ani ich ludności. Rosję postrzega Podhradský, podobnie jak Štúr, jako mocarstwo, ale nieuzurpujące sobie hegemonii 
w słowiańskim świecie z racji swej siły czy potęgi. Mocarstwową politykę Rosji tłumaczy misją, jaką ma do spełnienia wobec narodów stojących niżej w hierarchii rozwoju.

Program polityczny rosyjskich panslawistów wyglądał jednak trochę inaczej i mógł budzić obawy europejskich społeczności. Już Memoriał Aksakova $O$ kwestii wschodniej z 6 lutego 1854 roku wyraźnie mówił o nadejściu wielkiej epoki z trwałym sojuszem wszystkich Słowian pod patronatem cara ${ }^{6}$. Podhradský wykazuje zatem bądź zupełną niewiedzę, jeśli chodzi o kształt politycznego panslawizmu rosyjskich ideologów, bądź też celowo ten aspekt pomija.

Nowa sytuacja po roku 1867 generowała nowe spojrzenie na położenie narodów niewęgierskich w Koronie św. Stefana. Podhradský widząc miejsce Węgrów we wspólnocie słowiańskiej, wyraża przekonanie, że to ona właśnie może być gwarantem zachowania jedności królestwa. Polityka węgierska nie powinna zatem zmierzać ku sojuszom z narodami zorientowanymi antysłowiańsko, nie powinna nią kierować obawa przed panslawizmem, ucieleśniającym ideę postępu, ale wprost przeciwnie, powinna zaakceptować pozycję Słowian we wspólnym państwie:

Jedinká a jedna spása Mad’arov a spása c e l o s t i Štefanskej koruny, je večitá Allianza Mad'arov k politicko-národnej obapolnej slobode, - s Panslavis mo m, jako so všemohúcou myšlienkou historického pokroku; a menovito večité príatelstvo v identičnosti politicko-državnej so Slovanmi koruny sv. Štefana, v úplnej celosti zachovanéj (Podhratský, 1868, 23).

Przyjaźni słowiańsko-węgierskiej zapowiada długie trwanie, ponieważ leży ona w interesie zarówno Węgrów, jak i „uhorskich” Słowian, czyli Słowian zamieszkujących Królestwo Węgierskie. Jedni bez drugich nie mogą być wolni, co pokazała niedawna przeszłość, pozwalająca na rewizję wzajemnych relacji. Widzi je Podhradský jako trwały związek gwarantujący swobody narodowościowe i suwerenność polityczną:

Táto trpká a horká zkúšenost diktuje nám Slovanom následujúcu múdrost':

Nech sa kolečko času vrtí a prevracia jako chce, nikomu, ani kamarilili k vôli, na ničie šoptánie, nikdy viac s nemeckou politikou, ,proti” Mad'arom, ale vždy s Mad'armi až do najkrajniejšej „možnosti”k národno-politickej slobode,

${ }^{6}$ Szerzej na ten temat v. Walicki, 2002, 364. 
a k „uplnej” samostatnosti vlasti a koruny sv. Stefana nijako nerozdrobenej (Podhratský, 1868, 24-25).

Odnosi się tym samym zarówno do przeszłości, czyli postawy Słowaków podczas Wiosny Ludów, kiedy to związali oni swoje nadzieje z Austrią, jak i do przyszłości, opowiadając się za niepodzielnością Królestwa Węgierskiego. W tym aspekcie jego poglądy bliskie są poglądom Palárika. Jednakże Palárik - jak przypomina Tibor Pichler - „nehl'adal 'spásu' $\mathrm{v}$ rusofilstve, ale riešenie v uhorskom konštitucionalizme"7. Różniły się natomiast ich poglądy w kwestii oceny dualistycznej monarchii, która właśnie się ukonstytuowała. Zdaniem Podhradskiego dualizm, którego tak się Słowacy obawiali, jest na krótki czas potrzebny, stanowi bowiem pierwszy krok do zerwania z absolutyzmem i wejścia na drogę reform konstytucyjnych. Pálarik natomiast miał do dualizmu bardziej krytyczny stosunek, uważając, że służy on przede wszystkim interesom dynastycznym Habsburgów ${ }^{8}$.

Swój wywód zamyka Podhradský czteropunktową propozycją programową skierowaną nie pod adresem Słowaków, ale Węgrów. Sprowadza się ona do podsumowania wcześniej omawianych kwestii, takich jak zachowanie jedności Korony św. Stefana, zweryfikowanie stanowiska wobec Rosji, apel o nieangażowanie się w reorganizację Europy po przewidywanym rozpadzie Turcji, czy też rozwiązanie kwestii narodowościowych w duchu porozumienia.

W rozważaniach Podhradskiego, będących mozaiką różnych pomysłów, opartych często nie na argumentacji merytorycznej, a emocjonalnej, przebija przekonanie, że porozumienie Słowaków z Węgrami, narodem dojrzalszym politycznie, bardziej zgodnym, może przyczynić się do emancypacji Słowaków. Podobną rolę mogą też odegrać Słowacy w aspiracjach wolnościowych Węgrów. Tym, co wyróżnia narrację Podhradskiego, jest religijny horyzont, w jaki wpisuje swoje rozważania. Pozwala mu to na sformułowanie tezy, że Słowianie wspólnie z Węgrami staną się narzędziem powszechnego odrodzenia. Zarysowana w broszurze wizja przyszłości Słowian odwołuje się do idei mesjańskiej. Nadchodząca epoka

${ }^{7}$ Tibor Pichler w krótkim, syntetyzującym tekście stara się precyzyjnie przedstawić poglądy Palárika w politycznych ramach monarchii (Pichler, 1998, 83).

${ }^{8} \mathrm{Na}$ temat austrosceptycyzmu Palárika v. Pichler, 1998, 83. 
będzie epoką realizującą boski plan historii. Królestwo Boże na Ziemi będzie dziełem Słowian. Podsumowując swoje refleksje stawia niemal znak równości między panslawizmem a mesjanizmem, przy czym, jak już podkreślałam, wyraźnie odróżnia panslawizm od panrusizmu, czyli, jak pisze politycznego panslawizmu, który postrzega jako katastrofalne rozwiązanie dla emancypujących się narodów słowiańskich.

Płaszczyzna religijna wyznacza również ramy rozważań Michala Miloslava Hodžy - bliskiego współpracownika Štúra w latach 40. - zawartych w jego niepublikowanym liryczno-dydaktycznym poemacie Vieroslavín. Zaprezentowana $\mathrm{w}$ nim zostaje najpełniejsza w literaturze słowackiej wykładnia idei mesjańskiej. Ale to, co najważniejsze z punktu widzenia obecnych rozważań, to jego propozycje uporządkowania przestrzeni europejskiej w nowej sytuacji po roku 1867 i określenia w niej miejsca i roli Słowaków. Propozycja tym bardziej warta uwagi, że ujawnia skrajnie odmienną postawę autora $\mathrm{w}$ porównaniu z poglądami, jakie głosił bezpośrednio po roku 1849, po upadku Wiosny Ludów. Podobnie jak większość słowackich działaczy narodowych dawał wtedy wyraz swojemu rozczarowaniu wobec polityki Wiednia, któremu towarzyszyła niezwykle ostra krytyka własnego narodu. Najbardziej radykalny rozrachunek z niedawną przeszłością zawarł w poemacie Matora, który publikacji doczekał się jednak dopiero w roku 2006. W Vieroslavínie natomiast dokonuje wolty w przeciwnym kierunku. Prezentuje się jako absolutnie lojalny obywatel Monarchii, jej „,wierny syn”, który przyszłość słowiańskiego świata wiąże z Austrią.

Hodža, w przeciwieństwie do Podhradskiego, znaczniej mniej uwagi poświęca kwestii relacji słowacko-węgierskich. Jego myśl biegnie znacznie dalej, poza granice dualistycznej monarchii, poza horyzont Europy, w stronę wielkiej ogólnoludzkiej wspólnoty. Aczkolwiek nie ulega wątpliwości, że cały jego projekt historiozoficzny, prezentujący wizję starego kontynentu, sytuuje się w opozycji do lansowanej przez Węgrów idei jednolitego państwa narodowego, która siłą rzeczy ograniczała prawa narodowe zamieszkujących Królestwo Węgierskie narodów słowiańskich. Sformułowane to zostało expressis verbis:

Politický národ-motovidlo!

Striel'ajú tot' z neho ako z diel, 
zvlášte tam, kde l’udom ako šidlo

cudzí jazyk tisnú do hrdiel,

zvlášte tam, kde šlachty plemä zbrydlo

$\mathrm{v}$ telesnosti, do której sa skydlo

duchom svojim - žiada mnoho tiel!

Ktože toho narodu je tvorca?

Akú dal mu spásu za podiel?

Potvorná len vláda ducha borca,

Čo mat' nechce z l'udu nič, len škorca! (Hodža, s. 136).

Idea narodu politycznego jest zdaniem słowackiego myśliciela absolutnie nieuzasadniona, obca potrzebom narodów słowiańskich, lansowana przez szlachtę wbrew woli ludu. Co do tego, że wiązała się ona z nasilającą się madziaryzacją, nie mają wątpliwości również młodzi węgierscy historycy we wspomnianym dziele Rozštiepená minulost':

Obrovský rozdiel medzi snom o národnom štáte a skutočnost'ou chceli uhorsko-mad'arské vlády znížit' jednak usilovnou mad'arizáciou štátnej správy, jednak vytvorením silnej mad'arskej strednej vrstvy a lojálnej elity (čo znamenalo mad'arizovanie národnostných elít) (Zahorán, 2013,103).

Podobnie oceniał sytuację Ján Francisci, który w liście pisanym w listopadzie 1869 roku do Jána Mallego tak reagował na informację o możliwości rozmów na temat współpracy władz węgierskich z adresatem listu, będącym przedstawicielem Novej školy slovenskej”:

Podl'a môjho presvedčenia povol'nost' k Nemad'arom, lebo ide o národoch nemad'arských, či u Mad'aroch, či u vlády je nie reč, naskrze neleží v systéme uhorskej vlády, a rozpoloženie ducha a mienky mad'arského národa je ešte väčšmi výtečná. Dôkazom toho je celá ústrojnost’ skutku v najmocnejších zákonoch určená, ktorá v zákonodarstve, v administrácii, v školstve, súdobníctve, slovom, v každom odvetví, na ktoré dosial' zakon donesený je, zakonom 44:1868 zásadne vyslovenú národnu unifikáciu prakticky a mašinovou neúprosnost'ou prevádza $\mathrm{v}$ život štátu a občianstva až po najposlednejšie ohniva, v každom ohl'ade omnoho rozvetvenejšieho a rozširenejšieho štátneho organizmu, nežli pod Bachom, a robi to s úmyslom mad'arizácie (Eliáš, 2004, 129-130).

W dualistycznej monarchii miejsce Słowian, w tym również Słowaków, widzi Hodža w sojuszu z Austrią, którą postrzega jako terytorium

${ }^{9}$ Takie możliwości były przedmiotem rokowań pomiędzy „,uhorskim” Ministrem Spraw Wewnętrznych Pavlem Reinerem a Jánem Mallym, nie przyniosły jednak żadnych rezultatów. 
ogólnosłowiańskie, ojczyznę wszystkich Słowian. Nawiązując do obiegowego pojęcia Všeslavii, będącego filarem różnych projektów słowianofilskich i panslawistycznych, łączy je nie z Rosją, ale z Austrią:

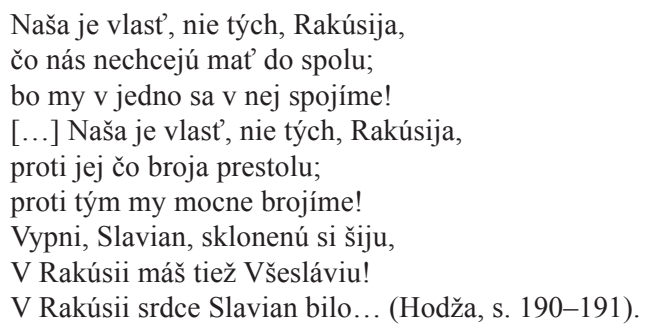

Mamy zatem nie tylko polemikę z lansowaną przez Węgrów ideą narodu politycznego, ale również polemikę z projektami panslawistycznymi. Krytyka koncepcji polityków węgierskich, jak również krytyka będących ich konsekwencją stosowanych praktyk madziaryzacyjnych nie oznacza jednak usunięcia Węgrów poza obręb przyszłej wspólnoty. Można by powiedzieć, że Hodža widzi w niej, pomimo iż nie ma złudzeń co do postawy Węgrów, miejsce dla tej części węgierskiej społeczności, którą już wcześniej wyróżniał jako warstwę podporządkowaną (lud):

Lebo na práv l'udských spolnej roli

Mad'arova pýcha streštená

nikdá nič nám vol’ne nepovolí,

do smrti sa radšej rozsápolí!

Mad'ar človek, to len pospolity,

ktorý k l’udstvu nášmu pristáva,

ač je v lesku pyšnej šlachty skryty,

človectvo mu Slovák priznáva:

na l'ud onen, šlachtou jeho zbitý,

prišiel Tatar, Turek zavalitý,

a on predsa mužne strváva!

Za to vlast'ou jeho lepšou bude

Rakúsije spolná dŕžava,

nežli tá, čo meno dal jej hrude,

tisíc rokov stal v jej manstva trude! (Hodža, s. 210).

Projekt Hodžy nie ogranicza się do zarysowania kształtu wspólnoty słowiańskiej ukonstytuowanej w ramach Austrii, ale zakrojony jest znacznie szerzej i obejmuje przestrzeń całej niemal Europy. Postulowana przez 
niego wspólnota europejska, oparta na idei wzajemnego porozumienia i poszanowania odrębności poszczególnych narodów winna obejmować wszystkie zamieszkujące ją narody chrześcijańskie: germańskie, romańskie i słowiańskie. Elementem określającym jej tożsamość powinny być wartości chrześcijańskie, a zwłaszcza wiara w Chrystusa. A chrześcijańska Austria mogłaby być gwarantem z jednej strony jedności, a z drugiej - zachowania narodowych odrębności. Taka Europa stwarza też szansę równouprawnienia dla Słowaków, którzy notabene są - zdaniem poety - narodem wybranym i im właśnie przypada szczególna rola budowania wspólnoty słowiańskiej, będącej częścią wspólnoty europejskiej. Tu dotykamy kwestii, które starałam się rozwikłać przy innej okazji, a mianowicie kształtu zawartej w utworze idei mesjańskiej ${ }^{10}$. Przypomnę, że w koncepcji słowackiego poety i myśliciela przeznaczeniem narodu słowackiego było - w planie Opatrzności - tysiącletnie cierpienie, zniewolenie, po którym może się odrodzić jako naród zajmujący wyjątkową pozycję w dziejach ludzkości.

Co ważne w tym projekcie - wspólnota słowiańska miałaby się ukonstytuować w ramach monarchii austro-węgierskiej. Jest to zatem koncepcja diametralnie odmienna od propozycji Štúra, który świat słowiański chciał całkowicie podporządkować mocarstwowej Rosji. Zapomniany poemat Hodžy potwierdza wielogłosowość słowackiego paradygmatu kulturowego, jest kolejnym przykładem krzyżowania się idei emancypacyjnych - zarówno w ramach jednego tekstu, jak i w uzupełniających się bądź polemicznych względem siebie narracjach.

Na postawione w tytule artykułu pytanie: przełom czy kontynuacja?, trudno odpowiedzieć w sposób jednoznaczny. Wizja Hodžy z całą pewnością stanowi przełom w stosunku do szturowskiej ideologii słowackiego nacjonalizmu z wpisaną w nią apologią twórczości ludowej i zamykaniem się we własnym kontekście kulturowym. Przynosi otwarcie na widocznego coraz bardziej w Europie ducha reform. Z drugiej strony można uznać, że jest kontynuacją austroslawistycznej ideologii Františka Palackiego. Większa trudność pojawia się w przypadku Podhradskiego, którego tekst

\footnotetext{
${ }^{10}$ Temu problemowi poświęciłam jeden z rozdziałów monografii Synowie Słowa. Myśl mesjanistyczna $w$ słowackiej literturze romantycznej, Warszawa 2008 oraz artykuł $W$ kręgu religii i polityki. Mesjanistyczny projekt Michala Miloslava Hodžy w tomie Wielkie spory małego narodu, Warszawa 2015.
} 
jest kompilacją różnych pomysłów, aczkolwiek dominuje w nim wątek „słowacko-węgierskiego" pojednania. W tym aspekcie przynosi on kontynuację tego nurtu słowackiej myśli politycznej, który stawiał na współpracę z węgierskimi liberałami, a który reprezentował Samo Vozár, Štefán Launer czy Ján Palárik.

\section{Literatura}

Demmel, J. (2013). „Slovenskí rodáci” a štvaví panslávi. W: Rozštiepená minulost'. Red. I. Kollai. Budapest: Nadácia Terra Recognita, s. 87-97.

Eliáš, M. (red.) (2004). Listy Jána Francisciho. Martin: Matica slovenská.

Florescano, E. (1985). Od historii - pomnika wtadzy, do historii wyjaśniajacej. W: Po co nam historia?. Wprowadzenie A. Moreno Toscano. Tłum. M. Mróz. Wstęp A. Łepkowski. Warszawa: PIW, s. 71-95.

Hodža, M.M. Vieroslavín. SNK, Archív literatúry a umenia, sygn. 46 HHH1.

Holec, R. (2013). Úvod bez záveru alebo úvaha namiesto úvodu. W: Rozštiepená minulost'. Red. I. Kollai. Budapest: Nadácia Terra Recognita, s. 11-16.

Kocák, M. [anonimowo] (1972). Jozef Podhradský (k problematike diela). W: K problematike slovenského romantizmu, Martin: Matica slovenská, s. 181-191.

Martinkovič, M. (2006). Idea uhorského vlastenectva a občianskej individuálnsti na križovatke politiských stratégií. „Filozofia” č.10, s. 838-858.

Osuský S., Úvodom. W: M.M. Hodža, Vieroslavin. SNK, Archív literatúry a umenia, sygn. $46 \mathrm{HHH} 1$.

Pichler, T. (1998). Národovci a občania: O slovenskom politickom myslení v 19. storočí: Bratislava:Veda.

Podhradský, J. (1868). Tajná história panslavizmu vôbec a uhorských Slovakov zláśte. Novi Sad: Platonova štamparija.

Walicki, A. (2002). W kręgu konserwatywnej utopii. Struktura i przemiany rosyjskiego stowianofilstwa. Warszawa: PWN.

Zahorán, C. (2013). Sen o národnom štáte. W: Rozštiepená minulost'. Red. I. Kollai. Budapest: Nadácia Terra Recognita, s. 98-113. 